\title{
Theorizing the Triple Helix model: Past, present, and future
}

\author{
Yuzhuo Cai \\ Faculty of Management and Business, Tampere University, Finland \\ yuzhuo.cai@tuni.fi \\ Henry Etzkowitz \\ International Triple Helix Institute, Silicon Valley, California, USA
}

\begin{abstract}
The Triple Helix of university-industry-government interactions, highlighting the enhanced role of the university in the transition from industrial to knowledge-based society, has become widespread in innovation and entrepreneurship studies. We analyze classic literature and recent research, shedding light on the theoretical development of a model that has engendered controversy for being simultaneously analytical and normative, theoretical, practical and policy-relevant. We identify lacunae and suggest future analytical trajectories for theoretical development of the Triple Helix model. The explanatory power of Triple Helix has been strengthened by integrating various social science concepts, e.g. Simmel's triad, Schumpeter's organizational entrepreneur, institutional logics and social networks, into its framework. As scholars and practitioners from various disciplinary and inter-disciplinary research fields, e.g. artificial intelligence, political theory, sociology, professional ethics, higher education, regional geography and organizational behavior join Triple Helix studies or find their perspectives integrated, new directions appear for Triple Helix research.
\end{abstract}

\section{Keywords}

Triple Helix model - Innovation - Sustainability - Theory building - Interdisciplinarity 


\title{
Arabic
}

\section{التنظير في إطار فوذج المراوح الثلاثة : الماضي والحاضر والمستقبل}

\author{
Yuzhuo Cai, Henry Etzkowitz
}

\begin{abstract}
الملخص
امتدت ”نظرية المراوح الثلاثة والتي تهتم بالتفاعلات بين الجامعة والهجال الصناعي والحكومة إلي الدراسات التي اهتمت بالإبداع

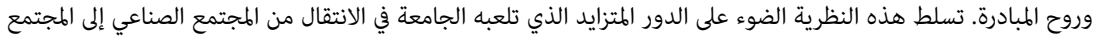

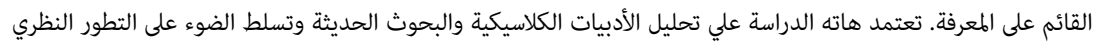

لنموذج أثار جدلا ليكون في نفس الوقت ذا صبغة تحليلية ومعيارية ونظرية وناجعا على المستوى السياسي ـ تكن الدراسة من

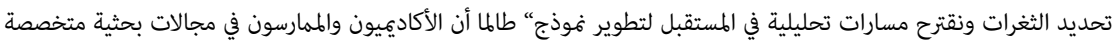

ومتعددة التخصصات مثل الذكاء الاصطناعي والنظرية السياسية وعلم الاجتماع والأخلاقيات المهنية والتعليم العالي والجغرافيا الإقليمية والسلوك التنظيمي يولون اهتماما للدراسات حول فموذج ـ على المستوى النظري. وقع تعزيز قدرة هذا النموذج على

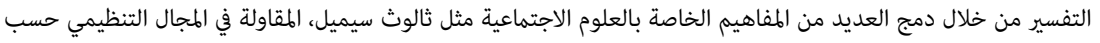

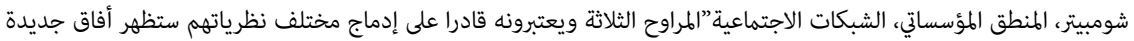
في الدراسات حول المراوح الثلاثة”المراوح الثلاثة .
\end{abstract}

الكلمات المفتاح

فهوذج المراوح الثلاثة، الابتكار، الاستدامة، بناء النظرية، الترابط بين التخصصات

\section{Chinese}

\section{理论化三螺旋模型：过去、现在和未来}

\author{
Yuzhuo Cai, Henry Etzkowitz
}

\section{摘要}

大学产业政府互动的三螺旋, 强调大学在从工业型向知识型社会过渡中 的重要作用, 它已经在创新和创业研究中得到广泛应用。我们分析经典文 献和最新研究, 阐明这个因同时具有分析性和规范性、理论性、实用性和 政策性而引来争议的模型的理论发展。我们确定现有研究中的缺陷, 并为 其理论发展的未来分析轨迹提供建议。通过整合各种社会科学概念, 
例如 Simmel 的三合会、熊彼特的组织企业家, 以及机构逻辑和社交网络 等, “三螺旋”的解释力得到了增强。由于来自各个学科和跨学科研究领 域的学者和实践者的加入, 如人工智能、政治理论、社会学、职业道德、 高等教育、区域地理和组织行为等领域, 三螺旋的研究或发现它们的观点 融为一体, 出现了新的三螺旋研究方向。

\title{
关键字
}

三重螺旋模型，创新，可持续性，理论构建，跨学科

\section{French}

\section{Elaborer une théorie du modèle de la Triple Hélice : passé, présent et futur}

\author{
Yuzhuo Cai, Henry Etzkowitz
}

\section{Résumé}

La Triple Hélice des interactions université-industrie-gouvernement, met l'accent sur le rôle accru de l'université dans la transition de la société industrielle à la société de la connaissance; elle s'est généralisée dans les études sur l'innovation et l'entrepreneuriat. Nous analysons la littérature classique et les recherches récentes, mettant en lumière le développement théorique d'un modèle qui a suscité la controverse car étant à la fois analytique et normatif, théorique, pratique et pertinent dans l'élaboration des politiques. Nous identifions les lacunes et suggérons des trajectoires analytiques futures pour le développement théorique du modèle de la Triple Hélice. Le pouvoir explicatif de la Triple Hélice a été renforcé par l'intégration dans son cadre théorique de divers concepts des sciences sociales, par exemple 'Triade' de Simmel, 'entrepreneur organisationnel' de Schumpeter, logiques institutionnelles et réseaux sociaux. Vu que des universitaires et praticiens de divers domaines de recherche disciplinaires et interdisciplinaires, comme l'intelligence artificielle, la théorie politique, la sociologie, l'éthique professionnelle, l'enseignement supérieur, la géographie régionale et le comportement organisationnel se joignent aux études de la Triple Hélice ou trouvent leurs perspectives intégrées, de nouvelles directions apparaissent pour la recherche dans le domaine. 


\title{
Mots-clés
}

modèle de la Triple Hélice - innovation - durabilité - construction de théorie interdisciplinarité

\section{Portuguese}

\section{Teorizando o modelo da Hélice Tríplice: passado, presente e futuro}

\author{
Yuzhuo Cai, Henry Etzkowitz
}

\section{Resumo}

A Hélice Tríplice das interações universidade-empresa-governo, destacando a melhoria do papel da universidade na transição da sociedade industrial para sociedade baseada no conhecimento, tornou-se difundida nos estudos de inovação e empreendedorismo. Analisamos a literatura clássica e pesquisas recentes, esclarecendo o desenvolvimento teórico de um modelo que gerou controvérsias por ser simultaneamente analítico e normativo, teórico, prático e politicamente relevante. Identificamos lacunas e sugerimos trajetórias analíticas futuras para o desenvolvimento teórico do modelo da Hélice Tríplice. O poder explicativo da Hélice Tríplice tem sido fortalecido pela integração de vários conceitos de ciências sociais, por exemplo a tríade de Simmel, o empreendedor organizacional de Schumpter, lógicas institucionais e redes sociais, em sua estrutura. Como acadêmicos e praticantes de vários campos de pesquisas disciplinares e interdisciplinares, por exemplo inteligência artificial, teoria política, sociologia, ética profissional, educação superior, geografia regional e comportamento organizacional juntam-se aos estudos da Hélice Tríplice ou encontram suas perspectivas integradas, novas direções aparecem para a pesquisa da Hélice Tríplice.

\section{Palavras-chave}

Modelo Hélice Tríplice - Inovação - Sustentabilidade - Construção de teorias, interdisciplinaridade 


\title{
Russian
}

\section{Теоретизация Модели Тройной спирали: вчера, сегодня, завтра}

\author{
Юджо Каи, Генри Иикович
}

\begin{abstract}
Аннотация
Тройная спираль взаимодействия университет-промышленность-государство, определяющая значимую роль университета в переходе от индустриального общества к обществу знаний, стала широко распространена в исследованиях, посвященных инновациям и предпринимательству. Мы проанализировали классическую литературу и недавние исследования, проливающие свет на теоретическое развитие модели, породившей противоречия вследствие ее одновременной аналитической и нормативной, теоретической и практической, а также программной основ. Мы также идентифицировали пробелы и наметили дальнейшие аналитические траектории для теоретического развития Трехспиральной модели. Объяснительная способность тройной спирали была усилена благодаря интеграции в модель различных социальных концепций, таких как Триада Зиммеля, организационное предпринимательство Шумпетера, институциональная логика и социальные сети.

С трехспиральной моделью работают ученые и практики из различных областей и междисциплинарных сфер исследования, таких как искусственный интеллект, политическая теория, социология, профессиональная этика, высшее образование, региональная география, организационное поведение, находя возможности для интеграции и новых направлений в исследовании Теории тройной спирали.
\end{abstract}

\section{Ключевые слова}

Теория Тройной спирали - Инновации - Устойчивость - Построение теории - Междисциплинарность 


\title{
Spanish
}

\section{Teorizando el modelo de la Triple Hélice: Pasado, presente y futuro}

\author{
Yuzhuo Cai, Henry Etzkowitz
}

\begin{abstract}
Resumen
El modelo de interacción universidad-gobierno-industria de la Triple Hélice, el cual resalta la relevancia del rol de las universidades en la transición de una sociedad industrial hacia una basada en el conocimiento, se ha popularizado en los estudios de innovación y emprendimiento. En este trabajo analizamos la literatura clásica así como investigaciones recientes con el fin de mostrar el desarrollo teórico de un modelo que ha generado controversia por ser simultáneamente analítico y normativo, teórico, práctico y relevante para la creación y gestión de políticas públicas. Además, identificamos lagunas y sugerimos trayectorias de análisis para el desarrollo del modelo de la Tríple Hélice en el futuro. El poder explicativo de la Tríple Hélice ha sido fortalecido con la integración a su marco teórico de varios conceptos de las ciencias sociales como son la triada de Simmel, el emprendimiento organizacional de Schumpeter, así como la lógica institucional y las redes sociales. Gracias a que académicos y especialistas de distintos campos de la investigación disciplinaria e interdisciplinaria — como la inteligencia artificial, la teoría política, la sociología, la ética profesional, la educación superior, la geografía regional y el comportamiento organizacional — se adhieren a los estudios de la Triple Hélice o integran distintas perspectivas, surgen nuevas direcciones para la investigación de la Triple Hélice.
\end{abstract}

\section{Palabras-clave}

Modelo de la Tríple Hélice - Innovación - Sustentabilidad - Construcción de Teoría Interdisciplinariedad

\section{Introduction}

The unique contribution of the triple helix model (Etzkowitz \& Leydesdorff 1995) to innovation studies is its attention to the heightened role of the university in the transition to a knowledge-based society. This focus contrasts 
to previous innovation approaches that focus on the firm or governmentfirm interactions. The university's enhanced relevance to technology transfer, firm-formation and regional renewal places it in a primary position in knowledge-based society in contrast to its secondary role in industrial society. Although most innovation approaches consider firms or the industry sector as a key element in innovation analysis (Foray 2015), all acknowledge the importance of university, industry and government and their interactions in fostering innovation and entrepreneurship. All approaches share in common key principles such as boundary spanning, interactive learning, and innovation's evolutional nature, in one way or another reflecting the basic rationale of Triple Helix.

The Triple Helix is sometimes used as a flag, a guiding heuristic, in a variety of innovation projects and proposals. Even without necessarily being aware of the model, some projects attempt to achieve a Triple Helix dynamic, typically by incentivizing universities to play a more active role in industrial and social innovation. Many of its proponents operate in a penumbra well beyond the core Triple Helix academic and policy community to which they have only an implicit and invisible link. The estrangement between the "inner" and "outer" Triple Helix communities, whichever they may be, represents both a problem and an opportunity. On the one hand, there is a broad community of practice that has moved without theory and, on the other, a relatively insular group of researchers and practitioners that has not yet caught up with Triple Helix initiatives engendered beyond their reach. Either over-academicization, inhibiting action while proliferating studies on Triple Helix or under analyzing the strengths and weaknesses of Triple Helix, which need to be taken into account in a robust initiative, are the Scylla and Charybdis of Triple Helix navigation.

Triple helix ideas of interconnected and partially autonomous institutional spheres are informed by the classic social theories of Simmel, Marx and Weber (Etzkowitz 2008: 24). Ironically, in advancing Triple helix, followers rarely build on its theoretical sources. Moreover, a variety of helical perspectives, such as Quadruple Helix (Carayannis \& Campbell 2oog), have emerged in recent years transcending the original triadic thesis. However, there is little enquiry trying to build synergies among those communities for advancing the Triple Helix model from different standpoints. This paper attempts to bridge the gap by asking the research questions: 1) What are the core theoretical rationales of Triple Helix model in its original form (the past of theorizing Triple Helix)?, 2) How have the current studies enhanced the theoretical rationales of Triple Helix (the present theoretical development)?, and 3) What are the future directions of theorizing Triple Helix (the future theory of Triple Helix)? In so doing, we analyze major studies developing theoretical foundations of Triple Helix. 
The Triple Helix model of innovation is used to foster regional economic growth and promote entrepreneurship, through understanding the dynamics of interactions between three institutional spheres of university, industry, and government. It also accounts for dynamic interactions between the three spheres through "taking the role of the other" in contexts where one or more of these triple helix actors are weak or constrained from acting (Etzkowitz 2008). The concept has taken on a life of its own and is used by various organizations, from municipalities to international agencies, as a framework for fostering interaction and innovation without fully acknowledging or having a full understanding of the concept.

Skeptics argue that Triple Helix is a normative concept rather than a neutral theoretical framework and criticize the model for lacking solid theoretical foundations (Cooke 2005: 1130; Shinn 2002: 6o9; Viale \& Pozzali 2010: 576). Others suggest that it has limited explanatory power for many practical issues (Brundin, Wigren, Isaacs, Friedrich, \& Visser, 2008; Giuliani \& Arza, 2009; Tuunainen, 2002), particularly when comparing between different contexts (Balzat \& Hanusch, 2004; Cai, 2014; Mowery \& Sampat 2004). On the other hand, the model has been generalized to apply to a wide variety of development contexts and cultures. Noting this tendency to universalization, Benneworth, Smith, and Bagchi-Sen (2015: 7) concluded: "If it is a concept that applies to every situation, then it is extremely difficult to understand how to apply it differently to different situations". Nevertheless, even some critics to Triple Helix acknowledge that the model "represents a critical and sometimes stringent base for further theoretical sociological reflection on innovation dynamics" (Marcovich \& Shinn 2011: 176).

Moreover, the Triple Helix model is challenged by proliferating helices. Taking into account "media-based and culture-based public" (Carayannis \& Campbell 2012), an expanded model is held to be more timely and suitable for addressing new features in contemporary society (De Oliveira Monteiro \& Carayannis 2017; Miller, McAdam, \& McAdam 2018), particularly related to the role of citizens. Development of the Triple Helix model, as a metaphorical extension of the DNA double helix, rooted in Georg Simmel's sociological concept of triads (Wolff 1950), was primarily based on inductive reasoning of successful practices of regional innovations in the past (up to the 199os). Given that other actors and factors can certainly be identified, it is not surprising that attempts have been made to expand the helical repertoire. For example, there has been a call for a Quadruple extension (adding the public or civil society as the fourth helix) with underlying Mode 3 knowledge production (Carayannis 
\& Campbell 2009, 2012). In empirical applications, the fourth helix has been identified as consumers (Ivanova, 2014); Users (Arnkil et al. 2010; Miller et al. 2018); Non-governmental organizations (Lindberg, Lindgren, \& Packendorff 2014); and Community (Doh 2018).

The EU has found Quadruple Helix to be a useful social context to disseminate responsible research and innovation (RRI) practices (European Commission 2016). Addition of a forth Helix, however, may likely explain innovation stasis as risks of taking radical steps are inhibited in Europe (Juma 2016). Carayannis, Barth, \& Campbell (2012) have further developed the model to Quintuple Helix, by adding "natural environments of the society" as the fifth helix. This step, however, introduces an anthropomorphic fallacy into the model. While the proliferation of extensions of the Triple Helix model is a testament to its fecundity, their validity should be carefully vetted. While some of these variations recognize the power of triadic interaction; others vitiate its force. Thus, we call for a renewal of the original core triadic model, with its focus on the entrepreneurial university, as a guiding framework for research and action.

Due to its "conceptual power to speak to all of these constituencies [university, industry, and government] simultaneously and to help them address particular intractable challenges related to the development of the knowledge economy" (Benneworth et al. 2015: 6), the Triple Helix model attracted policymakers of various contexts (Saad \& Zawdie 2011; Viale \& Etzkowitz 2010). It appears in scholarly research on national/regional innovation policies and practices in developed economies, e.g. Nordic countries (Solesvik 2017), Germany (Kreusel, Roth, \& Brem 2018), Japan (Yoda \& Kuwashima 2019) and Korea (Jungwon Yoon \& Han Woo Park 2017), BRICs countries (Daniels, Ustyuzhantseva, \& Yao 2017), i.e. Brazil (Almeida, 2005; Pique, Miralles, Teixeira, \& Gaspar 2019), Russia (Balzer \& Askonas 2016), India (Kumari \& Mallick, 2017), China (C. Liu \& Cai 2018) and South Africa (Patra \& Muchie 2018), and many developing countries across continents (Hladchenko \& Pinheiro 2019; Mêgnigbêto; Saad, Datta, \& Razak 2017).

The Triple Helix model has also been promoted by the World Bank, OECD, and the EU. In the World Bank Policy Paper Series on Pakistan (Speakman, Afzal, Yuge, \& Hanna 2012), the Triple Helix model is particularly used as a framework to analyze the innovation policies of the country and hence give policy recommendations. In 2013, OECD organized a workshop on "KnowledgeBased Entrepreneurship, the Triple Helix and Local Economic Development", as part of the XI Triple Helix Conference in London. Triple Helix networks have been explicitly addressed in the European Union (EU)'s Regional Innovation Strategies for Smart Specialization ('RIS3's strategies) (European Commission 2014b). Subsequently, the EU's ex-ante conditionality (a strategy for investment 
funds for innovation) requires for all member states to have in place the 'RIS3's strategies before they are eligible to receive Structural Funding (European Commission 2014a), as part of a statutory institutional governance repertoire in the EU (Benneworth et al. 2015).

There have also been efforts in developing Triple Helix indicators (Leydesdorff \& Park 2014) since Leydesdorff (2003); Leydesdorff and Meyer (2003) initially introduced a scientometric measurement of Triple Helix dynamics following a neo-evolutionary perspective. Leydesdorff's Triple Helix Indicators (available at https://leydesdorff.net/) have been applied to a variety of contexts, primarily in Leydesdorff's co-authored publications, such as in Germany (Leydesdorff \& Fritsch, 2006), Russia (Leydesdorff, Perevodchikov, \& Uvarov 2015), China (Leydesdorff \& Zhou 2014), South Korea (Kwon, Park, So, \& Leydesdorff 2012) and cross-country analysis (F.Y. Ye, Yu, \& Leydesdorff 2013). In the meantime, other measures of Triple Helix are developed, for example, by combining social network analysis and Triple Helix indicators (Kim \& Park 2012; Swar \& Khan 2013), developing a game-theory based measurement tool (Megnigbeto 2018), and constructing a simulation equation according to complete systems theory (W. Ye \& Wang 2019). The Global Entrepreneurial University Metrics (GEUM) project, organized by the International Institute for Triple Helix, led to an entrepreneurial university metrics that especially took hold in Brazil (Etzkowitz et al. 2017).

The Triple Helix model has been elucidated by Etzkowitz in his book Triple Helix: University-Industry-Government Innovation in Action (Etzkowitz 2008) and especially its second edition (Etzkowitz \& Zhou 2017), e.g. on the concepts of field theory, the role of Civil Society in triple helix, and the knowledge, consensus and innovation spaces. In addition, other scholars have contributed to developing theoretical foundations of Triple Helix, drawing from various theoretical insights, such as institutional theory (Cai 2014, 2015), social network theory (Deakin 2014), and game theory (Megnigbeto 2018). Other improvements include identification of enabling conditions (Cai, Pugh, \& Liu 2017; Ranga \& Etzkowitz 2013), the distinction between institutional spheres and functions (Zhou 2014), and circulation around the Triple Helix (Etzkowitz \& Dzisah 2012).

Originating in the early 1980's as an outgrowth of the entrepreneurial university concept of an academic institution actively involved in knowledge-based 
regional development (Etzkowitz 1983), it did not escape attention, especially in the analysis of MIT, that this often occurred through interaction with industry and government interlocutors (Etzkowitz 1993). The model was invented by observing, analyzing and putting a label on some new developments in innovation, in which economic growth is increasingly based on advances in science and technology. Etzkowitz identified triadic interactions to foster knowledgebased economic development in MIT President Compton's correspondence in the Institute's archives (Etzkowitz 1993). It was a conceptualization of the expansion of so-called public-private partnerships to include academia in solving dilemmas of a declining industrial region.

Universities were a strong institutional sphere in New England in the early 2oth century, especially the Massachusetts Institute of Technology (MIT), arguably the first and foremost entrepreneurial university, generating start-ups, from the late 19th century. MIT's President Karl Compton duly called university entrepreneurship to the attention of his industry and government colleagues in the New England Council and proposed it as the core of a strategy for regional renewal. Indeed, Compton had already proposed the strategy at the national level to address the depression as head of President Roosevelt's science advisory council but had not been able to gain sufficient support from his colleagues to take the idea forward.

Collaboration across the institutional spheres of university, industry, and government led to inventing the venture capital firm, systematically expanding happenstance academic start-ups into a regional renewal strategy (Etzkowitz 2002b). The essential elements of the New England experience were transferred to Northern California, where it was re-purposed to address the situation of an emerging knowledge-based region during the Post War. Under such conditions, the role of the national government in supporting the underpinnings of the technological enterprise was salient as an important element of a Triple as a normative policy as well as an analytical model (Etzkowitz 2011).

At the 1994 Meetings of the International Sociological Association, Leydesdorff invited Etzkowitz to propose a topic for an Amsterdam workshop. He suggested as a theme the expansion of university-industry relations to university-industry-government interactions that he had labeled "Triple Helix," inspired by the iconic DNA model, aware of Linus Pauling's discarded triple helix model for DNA. Society was more complex than biology and required a third helix to model innovation! In preparation for the workshop, they jointly elaborated the conceptualization of Triple Helix in a seminal work (Etzkowitz \& Leydesdorff 1995). In developing the Triple Helix model, Etzkowitz and Leydesdorff draw insights from multiple disciplines, such as "evolutionary economics, the sociology of science and technology, and the sociology of higher 
education, as well as policy analysis with an evaluative perspective" (Zhou, 2014: 4). Etzkowitz and Leydesdorff (2000) have further expounded the Triple Helix into a model for studying knowledge-based economies.

Since 1996, the concept of Triple Helix has been further developed through a series of workshops, conferences, and forums that have created a community of scholars, practitioners, and policymakers. By 2006 the Triple Helix Association was founded to sustain the community, enhance interaction among its members and to develop new initiatives, such as the founding of the Triple Helix Journal in 2014. To date, 17 Triple Helix conferences have been organized in five continents, along with numerous workshops, summits, and congresses.

The Triple Helix model captures "Innovation in Innovation" that is an enhancement in the conditions that produce knowledge-based innovation (Etzkowitz 2003). Interaction among the three spheres of university, industry, and government, especially at the regional and local levels, initiated by individuals and/or organizations that have convening power and command respect across the Triple Helix, has been found to be key to realizing the potential of a knowledge-base. Institutional reconfiguration for start-up support or technology transfer as well as the invention of new mechanisms are a key part of the concept (Etzkowitz \& Zhou 2017). Lacking an organizing process, a knowledgebase remains an unrealized potential (Etzkowitz 2013). In the past several years, activist Mayors in Chicago and New York have incentivized universities to commit to an entrepreneurial interactive stance (Etzkowitz \& Zhou 2018).

\subsection{The Triple Helix Model}

Etzkowitz and Leydesdorff (2000) distinguish three types of Triple Helix models, namely the "statist model", the "laissez-faire model", and the "balanced model" (Figure 1). The balanced model of Triple Helix "begins from two opposing standpoints: a statist model of government controlling academia and
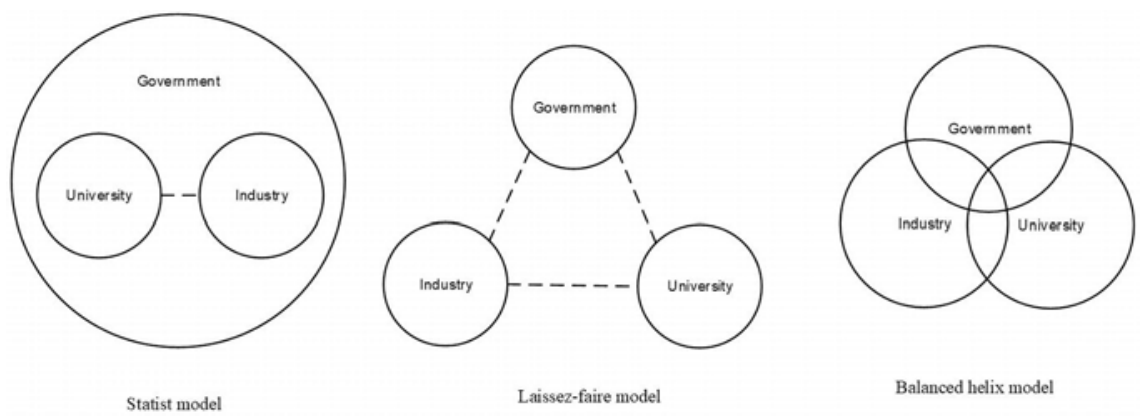

FIGURE 1 Three Triple Helix models 
industry, and a laissez-faire model with industry, academic and government separate and apart from each other, interacting only modestly across strong boundaries" (Etzkowitz 2008: 12).

In the statist model, the government controls both academia and industry and is expected to take the lead in developing projects and providing the resources for new initiatives. Examples can be seen in the former Soviet Union, France, and many Latin American countries. Zhou (2008) has especially elaborated a "government pulled Triple Helix" in the Chinese context, with the Communist Party in oversight.

The US experience at different historical points exemplifies the different Triple Helix models: World War II, the statist model, with university and industry coordinated by government, even as university and industry figures became part of government coordinating bodies. During the early Post War, the positing of an ideological laissez-faire triple helix model, reflected the political predispositions of iconic figures like Vannevar Bush, whose actions, in practice, represented a balanced model. A balanced model has largely arisen out of a dialectic between laissez-faire ideology and practical exigencies. Cold War competition called forth the creation of the Defense Advanced Research Projects Agency (DARPA), a government agency to take the lead in organizing triple helix innovation in response to the Sputnik crisis of 1957.

By including academics in the leadership of the agency, rather than making it responsible directly to a Minister, as in the current British proposal for a DARPA, the US DARPA had considerable leeway to determine US long term technology needs for defense, interpreted in the broadest fashion. Indeed, most of DARPA's significant successes from search algorithms to Global Positioning System (GPS) have been "dual use" with significant applications across civilian and military spheres. Other US triple helix initiatives like the Small Business Innovation Research (SBIR) program were constrained to the longterm realm of radical innovation, out of ideological concern for government becoming too involved in close to the market, more incremental technology development, regarded as the proper sphere of industry (Etzkowitz et al. 2000).

In the laissez-faire model, industry, academia, and government are separate and independent of each other. These actors interact only modestly across strong boundaries. The laissez-faire model also reappears under ahistorical conditions of over-weening success such as contemporary Silicon Valley, where the role of government and university, strong and salient, in the regions formative years, have been largely forgotten and overshadowed by entities, like Apple, Google and Facebook, that have grown from start-up to megacorporation in a relatively short time period. The statist variant is arguably the "ur" triple helix, recognizing its predecessor the so-called Sabato's Triangle 
knowledge-based innovation model utilized by military governments in Argentina and Brazil from the 1960"s to 1980's (Adler and Adler 1987). This "ur" denotes someone or something regarded as embodying the basic or intrinsic qualities of a particular class or type.

The global tendency is towards a balanced model, "from one of strong boundaries between separate institutional spheres and organizations to a more flexible overlapping system, with each taking the role of the other" (Etzkowitz 2002b: 2). It is argued that "The balanced configuration offers the most important insights for innovation because the most favorable environments for innovation are created at the intersections of the spheres" (Ranga \& Etzkowitz 2013). It is at these intersections, that under favorable conditions, to be specified hereafter, that boundary walls may be transformed into "boundary spaces" and new formats for interaction are invented, drawing from different spheres (Champenois \& Etzkowitz 2018).

However, a pure model with balanced interactions between the three spirals of university, industry, and government, hardly exists in reality. Indeed, strong imbalances among the helices may deplete even the most successful innovation system. For example, in contemporary Silicon Valley, a highly successful private sector in tandem with a weak public sector makes it difficult to maintain a sufficient educational infrastructure to support firm needs for talent (Scott, Kirst, \& Colleagues, 2017). Strengthening the public sector would be in the long-term interest of the private sector but crises in housing, transportation, and education have thus far only been met by palliative measures (Etzkowitz \& Steiber 2018). A deeper crisis, the loss of much of New England's traditional economic base in the early 2 oth century inspired an effort to redress the regional imbalance by creating lateral innovation governance structures.

\subsection{The Rationale of Triple Helix}

Basically, there are five major aspects of the rationale of an ideal-type or a normative balanced model of Triple Helix that foster optimal conditions for innovation.

First, the theoretical core of the Triple Helix model is its consideration of triadic interactions as an Occam's razor principle (Walsh 1979). The core of the Occam's razor principle is about necessity; "if it is not absolutely necessary to introduce certain complexities or hypothetical constructs into a given explanation, then don't do it" (Braithwaite, 2017: 2). Triple Helix explores the implications of classical sociologist Georg Simmel's micro levels analysis of dyads and triads (Wolff 1950) at the meso level of organizational interaction, in addition to the classic intermediating properties of the Tertius Gaudens. Tertius Gaudens, the third party, takes advantage of the interactions between two 
parties for competition against each other or gaining favor from each other, leads to benefits (Wolff 1950). In the Triple Helix model, the third element also introduces a propensity for innovation, especially in organizational innovations and the invention of new organizational formats such as the venture capital firm (Etzkowitz 2002a). The Triple Helix model, in its original elaboration, focuses on the reciprocal relations/interactions between the three sectors of university, industry, and government (Etzkowitz \& Leydesdorff 1995, 1997).

Second, the core mechanism underlying the Triple Helix interactions as optimal condition for innovation is "taking the role of the other" (Etzkowitz 2008), performing new roles as well as their traditional functions. Organizations taking non-traditional roles are viewed as a major potential source of innovation in innovation. For instance, firms continue to produce goods and services, but also do research and provide training at high levels (e.g. through the corporate university). The government is responsible for resolving market failures, adjusting public policies and establishing market rules, but also makes available venture capital to start new enterprises, particularly for high-risk businesses. Universities keep their traditional roles of teaching and research, but also devote effort to the capitalization of knowledge, patents, and start-up companies. Indeed, an increasing number of universities have evolved an increasingly complex innovation system, starting with technology transfer offices, incubators and science parks, extending into translational research and extension of entrepreneurship education across the campus. These activities are often in the guise of design thinking or into an ecosystem that comprises a penumbra that encompasses and illuminates traditional academia (Rice 2019) through a bi-directional flow, instantiated in faculty members who carry out varying proportions of their in academia and other institutional spheres (Dzisah \& Etzkowitz 2008).

Third, evolutionary mechanisms are underlying the development of the Triple Helix model. However, the model is not the result of a self-organized evolution; rather the process of development needs to be pre-structured/ coordinated (Leydesdorff \& Meyer 2006), e.g. through innovation policies (Cai et al. 2017) or agency (Cai \& Liu 2020). Etzkowitz (2008: 21) noted that the spirally-developing triple helix is "a synthesis of evolution in the vertical axis and circulation in the horizontal". While "taking the role of the other" mainly reflects the horizontal circulation in terms of observable actions, it results in the evolution of each of the three spheres, in the vertical axis, and the model of their interactions. Etzkowitz and Leydesdorff respectively take neo-institutional theory and neo-evolutional theory perspectives when understanding evolutionary mechanisms (Leydesdorff, 2012: 29-30). From an institutional theory perspective, as the environment, i.e. the patterns of triple helix 
interactions between university, industry, and government, in a regional or nation may change over time, the "genes" of organizations in the three sectors may mutate with the changes in the environment. From an evolutional perspective, the three functions, namely wealth generation, knowledge production, and normative control, are respectively the three evolutional mechanisms. While traditional evolutionary economics mainly deal with two sub-dynamics in the form of co-revolution, the triple helix configuration includes three sub-dynamics, including market, innovation, and control (Leydesdorff 2000, 2012; Leydesdorff \& Meyer 2006).

Fourth, when it comes to the coordination for developing the Triple Helix interactions, the core is to enable functional mechanisms mediating between top-down and bottom-up initiatives. Part of the role of government in Triple Helix interactions is developing innovation policies and initiating priority innovation program in a top-down manner. However, the dynamic of Triple Helix also relies on bottom-up initiatives, which is in conjunction with "an active civil society in which initiatives are encouraged from various parts of society role" (Etzkowitz, 2008, p. 11). Both top-down and lateral coordination and bottom-up initiatives are dimensions of the Triple Helix model.

Fifth, to build optimal conditions for innovation in innovation, leadership and capabilities are required. Triple Helix interactions are enabled in two types of conditions, sufficient condition of convening authority and necessary condition of innovation capacity. Convening authority can be seen in the early 2oth century New England, when representatives of the three helixes were convened by political authorities to address an innovation gap (Etzkowitz 1993, 2002a). In 199o's Silicon Valley, industry took the lead. The essential principle was that: activation of a triple helix requires leadership by persons and organizations who have the respect of all the key players. This principle was confirmed by a later failure case (1990's New York City) in which once the initial convener passed on the convening role to an organization, lacking gravitas across the helices, the initial effort dissipated (Etzkowitz \& Zhou 2017).

Innovation capacity as the necessary condition is about the existence of and/or ability to create a knowledge-base with commercialization potential. This may be ascertained by traditional research and development (R\&D) measures such as Business Enterprise Expenditure on R\&D (BERD) and Gross Domestic Expenditure on Research \& Development (GERD) supplemented by patents, disclosures and other indicators of innovation potential of a knowledge base. However, traditional $R \& D$ measures only represent a relatively small proportion of the knowledge potential available. Etzkowitz (2014) argues that the store of existing knowledge also available in teaching universities includes the arts as well as the sciences. 


\section{Enhanced Theoretical Foundations of the Triple Helix Model (The Present)}

In this section, we will analyze an array of studies that advance theoretical foundations of the Triple Helix, using the lens of five rationales of Triple Helix, mentioned above.

\subsection{Triadic Interactions}

Ranga and Etzkowitz (2013) introduced the concept of Triple Helix systems as an analytical construct that synthesizes the key features of Triple Helix interactions with the innovation systems approach. Triple Helix systems are sustained by three key aspects, namely components in the systems, relations between the components, and functions of the systems. The basic components consist of the institutional spheres of university, industry, and government. In each of the spheres, there are "a wide array of actors, among whom a distinction is made between: (a) individual and institutional innovators; (b) R\&D and non-R\&D innovators; and (c) 'single-sphere' and 'multi-sphere' (hybrid) institutions" (Ranga \& Etzkowitz 2013: 238).

Other studies have identified new actors in Triple Helix systems, such as hybrid organizations in "boundary space" (Champenois \& Etzkowitz 2018), intermediaries including ad hoc organizations (Poppen \& Decker 2018), legal firms (Reich-Graefe 2016) non-governmental agencies (Tamtik 2018) and individuals (Mandrup \& Jensen 2017). Also, an analysis of the Triple Helix in Israel distinguishes between three core actors and six supporting actors (Drori 2013). Although these studies indicate a variety of actors contributing to regional innovation, they have largely confirmed that university, industry, and government are primary actors because of their most significant roles in fostering innovation. The actors can also be distinguished between primary and secondary layers (X. Liu \& White, 2001). According to the Triple Helix thesis, it is important to keep triadic interactions in the first layer.

To understand the increasing importance of sustainable development and civic engagement in the innovation process (Kimatu 2016), some competing concepts are developed, such as the Quadruple Helix model (Carayannis \& Campbell 2009). However, Etzkowitz and Zhou (2006) consider that "adding a fourth helix might cause the triadic model to lose its ... dynamic properties of a tertius gaudens". To resolve this paradox, Etzkowitz and Zhou (2006) propose a model of Triple Helix twins, adding an alternative university-public-government Triple Helix as a complement to the universityindustry-government Triple Helix, which respectively represents the sustainability and innovation dimension of the Triple Helix. 


\subsection{Taking the Role of the Other}

While "taking the role of the other" has been claimed as the key mechanism underlying the Triple Helix interactions, there is lacking theoretical accounts on why it can promote innovation. Some recent studies shed light on possible theoretical explanations, drawing insights from institutional theory and social network theory respectively.

Cai and Liu (2020) have paved the way for explaining the mechanisms of "taking the role of the other" by integrating the insights of two concepts of institutional theory, namely institutional logics (Thornton, Ocasio, \& Lounsbury 2012), and institutional entrepreneur (Battilana, Leca, \& Boxenbaum 2009) in their study on analyzing the role of university as institutional entrepreneur in regional innovation. "Institutional logics are the shared conceptual and normative frameworks that provide guidelines for the behavior of field participants" (2009: 8) (Scott, Kirst, Biag, \& Sipes 2017). Institutional entrepreneurs refer to the actors who not only initiate diverse changes in the institutional environment but also actively participate in the implementation of such changes (Battilana et al. 2009).

In each of the spheres of university, industry, and government, there are certain dominating logics, such as professional logic, corporate logic, and bureaucratic logic respectively (Cai \& Liu 2020). One central pervasive argument of the institutional logics perspective is that multiple and contending logics provide the dynamic for a potential change in both organizations and societies (Thornton et al. 2012). Thus, when each of the university, industry, and government takes the role of the other, this entails cross-field actions thus creating multiple institutional environments, which provide conditions conducive to institutional entrepreneurship (Battilana et al. 2009).

Although social network theory has been introduced in Triple Helix research mainly for analyzing the patterns of interactions among different actors (e.g., Peng, Zhang, Han, Ding, \& Fu 2019; Pinto, 2017; J. Yoon \& H.W. Park 2017), it unique sociological insights may potentially help theorize the Triple Helix mechanisms. In his seminal work, Granovetter (1973) contends that the strength of weak ties lies in its nature of being a source of novel information. When applying social network theory in the context of innovation, it has been suggested that stimulating innovation within networks requires a combination of both strong and weak ties (Abrahamson \& Rosenkopf 1997; Capaldo 2007; Michelfelder \& Kratzer 2013). "Weak ties aid exploration (the generation of new ideas), whereas strong ties aid exploitation (the implementation of new ideas)" (Barrie, Zawdie, \& João, 2019: 212). The creation and diffusion of innovation are mostly attributed to weak ties (Gretzinger, Hinz, \& Matiaske 2011).

The perspicacity of "intermediate ties", a concept that the authors are working in another research project, is that they provide indirect support to innovation 
and entrepreneurship as a "gift" relationship in which a direct return is typically neither required nor expected. Social capital, freely exchanged through intermediate ties constitutes the basic building blocks of entrepreneurial support structures, translational processes and polyvalent knowledge (Viale \& Etzkowitz 2010). Going beyond the recent efflorescence of entrepreneurship courses, a strategy of academic redesign focused on promoting intermediate ties as the micro-foundations of entrepreneurship, is recommended. Venues to encourage informal interaction are an initial step to academic restructuring that prioritizes inter-disciplinary project groups as a modality of research and education.

\subsection{Evolutionary Process}

Leydesdorff 's work reinterprets Triple Helix from the standpoint of evolutional economics, focusing on processes susceptible to quantitative analysis rather than actorsmore suitable to qualitative capture(e.g.,Leydesdorff 2000, 2018; Leydesdorff \& Deakin 2011). According to Leydesdorff, the focus on the technological trajectories based on co-evolution between two dynamics, i.e. markets and technologies and the political economy pays special attention to co-evolutions between state control and markets (Leydesdorff 200o). Each dynamic can be understood as a selection mechanism. Whereas co-evolution can stabilize or lockin a trajectory, because of "mutual shaping" along the trajectory between the two selection mechanisms, a third dynamic, introduced by the Triple Helix model, "can be expected continuously to upset this tendency toward equilibrium to the extent that such a system becomes unstable" (Leydesdorff, 2018: 16).

Cai $(2014,2015)$ re-interprets Etzkowitz's (2008) description of Triple Helix evolution from the perspective of institutionalization, the process "by which social processes, obligations, or actualities, come to take on a rule-like status in social thought and action" (Meyer \& Rowan 1977: 341). Consequently, Cai distinguishes four development stages in the process of the institutionalization of the Triple Helix model, namely Stage 1: Realization of the needs; Stage 2: Intraorganizational transformation; Stage 3: Interactions between organizations in the three sectors; Stage 4: Institutionalization of the Triple Helix model. The evolution of Triple Helix in each stage is associated with certain institutional environmental factors (Cai 2015).

\subsection{Mediating between Top-down Coordination and Bottom-up Initiatives}

The recent debates over expanding the Triple Helix model have made explicit the theoretical ground concerning the role of civil society in mediating between top-down coordination and bottom-up initiatives. Leydesdorff and Etzkowitz (2003) do not consider the necessity of transforming the Triple Helix to Quadruple Helix, because civil society is not an institutional sphere on the 
same level as university, industry or government but rather an overarching societal framework, guaranteeing freedom of speech and organization-formation initiative, in which the Triple Helix has most efficaciously evolved. Civil society can serve as a buffer zone between the control of authorities and private initiatives (Seppälä 1992: 2) and thus facilitates both top-down governance and grassroots initiatives to best interact and engage with each other in innovation processes (Carayannis \& Campbell, 2012:3). Although civil society may provide ways of integrating top-down and bottom-up initiatives, its potential in instigating triple helix interactions is only treated in some rare case studies (e.g., Etzkowitz 2014).

\subsection{Conditions of Triple Helix}

Synthesizing relevant literature, Cai, Pugh, and Liu (2015) have systematically identified a list of enabling conditions that facilitate the Triple Helix interactions of university, industry, and government. These conditions are either tangible (in the technical environment) and intangible (in the institutional environment). The tangible conditions are mainly based on the description of the Triple Helix system by Ranga and Etzkowitz (2013). Basically, there are the following major tangible enabling conditions: 1) Competencies of universities in knowledge and technology generation and diffusion, 2) Absorptive capacity and demand of industry and innovator for knowledge and technology, 3) Supportive infrastructures, including policy and fiscal measures for formation and development of high-tech start-ups, university spin-offs, and other kinds of organizations for university technology transfer, and 4) Institutional entrepreneurs who enunciate a vision for knowledge-based development and bring leadership of the three spheres together.

The intangible conditions are seven logics that are aligned with activities of a balanced model of Triple Helix originating from successful innovation stories in Western societies (2015). These logics are: 1) Shared beliefs in knowledge as a key to economic growth, 2) Market orientated organizational culture, 3) Effective intellectual property protection system, 4) Strong sense of competition, 5) Process management in knowledge production, 6) Civil society 7) Democratic policymaking. Using such institutional logics as a benchmark to examine the Triple Helix development in China, Cai (2014) find that while the first four institutional logics are becoming similar to those in the West, the rest three logics aligned with the Triple Helix activities in the West are largely absent in China. Due to specific institutional context in China, unique paths of Triple Helix development have been discovered in different Chinese regions (Cai \& Liu 2015; C. Liu \& Cai 2018). Even in many European regions, the three actors of university, industry, and government remain in their corners but do not engage (Martin 2018) or interact only in their 
traditional capacities (University of Bath 2018). This implies a need to "turn Triple Helix on its head" and ask why innovation and entrepreneurship are constrained as well as how it arises. The perspective of enabling conditions may help resolve the puzzles.

"Lundvall notes that what qualifies as a good theory of innovation is not carved in stone but has to evolve as a result of changes in society and our attempts to understand these challenges" (Fagerberg, Martin, \& Andersen 2013: 7). When entering into the 21st century, society has undergone fundamental changes, e.g captured by several interrelated concepts, such as knowledge-based society 2.0 (Rutten \& Boekema 2012), innovation ecosystem (Jackson 2011), platform economy (Kenney \& Zysman 2016), globalization 3.o (Friedman 2005) and industry 4.0 (Ustundag \& Cevikcan 2018). These concepts reflect the following major transformations in our society: Knowledge is not only simply distinguished between tacit and codified type, but also being context-dependent; The elements/actors in innovation ecosystem are diverse and are becoming increasingly interdependent to each other through unobvious links; Social responsibility has become a norm in innovation activities; The cornerstone of globalization has been shifted from countries and companies to individuals and groups (Cai and Lattu 2019). Such transformations are accompanied with sustainable development in the environmental, social and economic dimensions (Elkington 1998). The conflicts between the goals of the three dimensions can lead to tensions with and between different innovation sectors (Hahn et al. 2015; Lattu and Cai 2020). The future theoretical development of Triple Helix should also address these new features of and challenges in contemporary society.

\subsection{Civil Society in Triple Helix}

People often perceive that the notion of Quadruple Helix (Carayannis \& Campbell, 2009) brings civil society into the analysis of dynamics in regional innovation. However, according to Triple Helix scholars, the civil society is even too important to be considered as a parallel helix in addition to university, industry, and government, but "the launch pad for take-off triple helix interactions" (Etzkowitz, 2014, p. 19) or the institutional ground of Triple Helix (Cai, 2015). Nevertheless, the current Triple Helix model has not explicitly elucidated civil society in its analytical framework.

In a recent conference paper, Cai and Lattu (2019) proposed a civically engaged Triple Helix model (Figure 2) by synthesizing the literature of Triple 


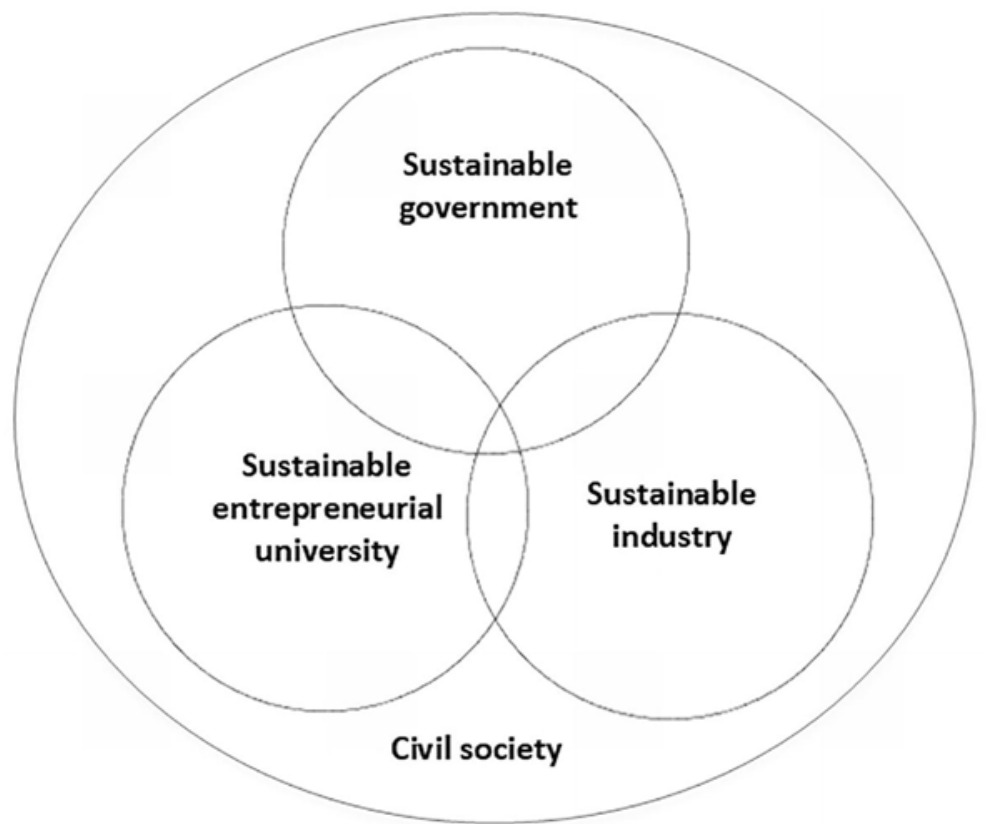

FIgURE 2 The Civically engaged Triple Helix Model SOURCE: MODIFIED FROM CAI AND LATTU (2019)

Helix and Quadruple Helix, mainly to address one challenge in maintaining reciprocal relations in Triple Helix interactions: the goals of actors for sustainable innovation from different sectors differ in terms of time-span. For instance, professors engaged in Triple Helix may be interested in long term societal benefits, while entrepreneurs might be short-sighted. In some cases, the situation could be just opposite (entrepreneurs have longer time visions than academics) as the cases described by Hiltzik (2000) on the riveting story of the legendary Xerox PARC. The different temporal perspectives of Triple Helix actors will hamper their effective integrations, thus affecting the outcomes of innovation. Cai and Lattu (2019) posit that a shared commitment to social responsibilities and sustainable goals help aligns the interests and goals of Triple Helix actors. In so doing, civic engagement is crucial. Accordingly, they call for a future research agenda of considering the three triple helix sectors, namely sustainable entrepreneurial university, sustainable corporation, and sustainable government.

\subsection{New Analytical Layers on Government}

While Triple Helix has been mainly used in research and practices of regional innovation, it faces challenges when innovation systems are internationally 
interconnected (Barnard \& Chaminade 2011; J. Liu, Chaminade, \& Asheim 2013; Necoechea-Mondragón, Pineda-Domínguez, Pérez-Reveles, \& Soto-Flores 2017; Pandey \& Desai 2017). Moreover, in the practices of some regions, different layers of government may intervene with each other. The role of governments of various layers may change along with time-lapse. For instance, in their case studies of regional innovation in China, Cai and Liu distinguish national and regional governments in their Triple Helix framework for analysis (Cai \& Liu 2015; C. Liu \& Cai 2018). In the development of the Tongji Innovation Cluster in Shanghai, Cai and Liu (2015) found that in the beginning, the main actors are only from university and industry, with the absence of government. Then the local government was involved as a facilitator of university-industry interactions, but in the end, the central government took over the coordinating responsibility, replacing the role of local government. This model is called the "delayed government-led model" (Figure 3). In the case of Shenzhen Economic Zone, the initiative is solely made by the central government but gradually its role is much weaker than the local government. This model is named "Statistfading balanced Triple Helix model" (Figure 4) (C. Liu \& Cai 2018).
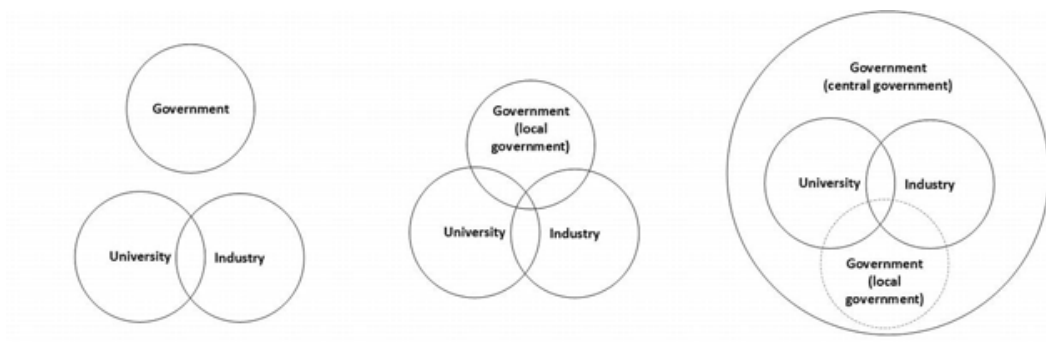

FIGURE 3 Delayed government-led model SOURCE: CAI AND LIU (2015)

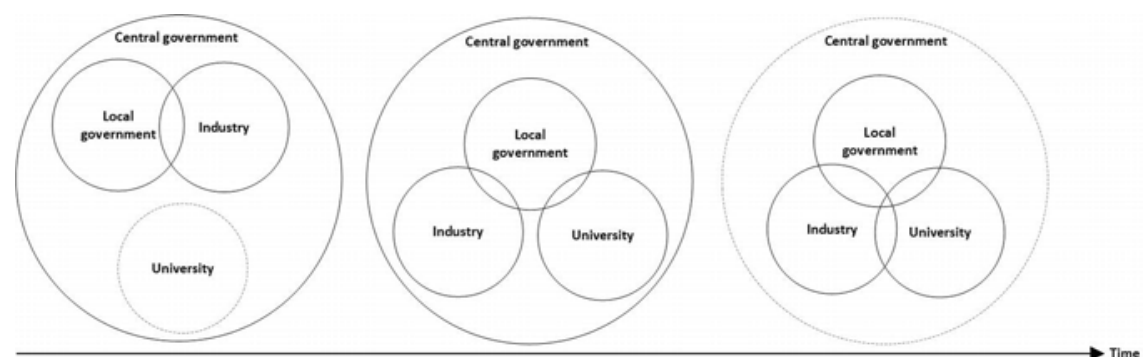

FIGURE 4 Statist-fading balanced Triple Helix model SOURCE: C. LIU AND CAI (2018) 
Although the example studies focus on the Chinese context, the role multilayer governments in developing a Triple Helix model can be found in other nations as well. Such a perspective may help resolve some dilemmas in Triple Helix analysis, which tend to look at government as one single sector. Nevertheless, in the original New England case, the inter-related roles of state and national government were outlined, showing how their activation to address innovation issues could only fully occur in a broader context, given ideological constraints on government leadership (Etzkowitz 2008).

\subsection{The Global Dimension of Triple Helix}

While the innovation processes are becoming globally interconnected (Barnard \& Chaminade 2011; J. Liu et al. 2013; Necoechea-Mondragón et al. 2017; Pandey \& Desai 2017), the actors in a regional innovation system not merely interact with other actors in the same locality but also with those in the neighbor regions and the regions across national borders. As a response to such a situation, Cheng et al. (2019) proposed a novel model of Triple Helix, in which they add the dimension of globalization, positioning it in the middle of the Triple Helix framework. Instead of considering putting globalization as a separate dimension, Cai, Ferrer, and Lastra (2019) add the transnational dimension to the three spaces and three cooperation spheres respectively in their proposed the transnational Triple Helix model (Figure 5)

\subsection{Trust Building among Triple Helix Actors}

While the synergy potential may be built between actors from different worlds of work and values systems, to what extent the potential can be realized depends on the trust among these actors (Bychkova, Chernysh, \& Popova, 2015). Innovation studies suggest that trustworthy social relationships are also beneficial for interactive learning and innovation (Boschma 2005). While the most useful knowledge/ideas would come from weak ties (the links between two different communities), one challenge is that the level of trust between actors connected by weak ties might be low; the trust issue is even more important when the knowledge is tacit (Levin \& Cross 2004). The concept of intermediate ties, dealing with non-kinship trust relationships, may offer a useful insight when making trust analysis in the Triple Helix interactions.

\section{$5 \cdot 5$}

\section{Linking Macro-level to Micro-level Mechanisms}

To fully understand the dynamics of Triple Helix and develop it as a useful tool for innovation analysis, there is an urgent need to explore micro-level mechanisms. In this regard, social network theory has been used in tracing individual linkages of Triple Helix interactions. For instance, when analyzing academics 


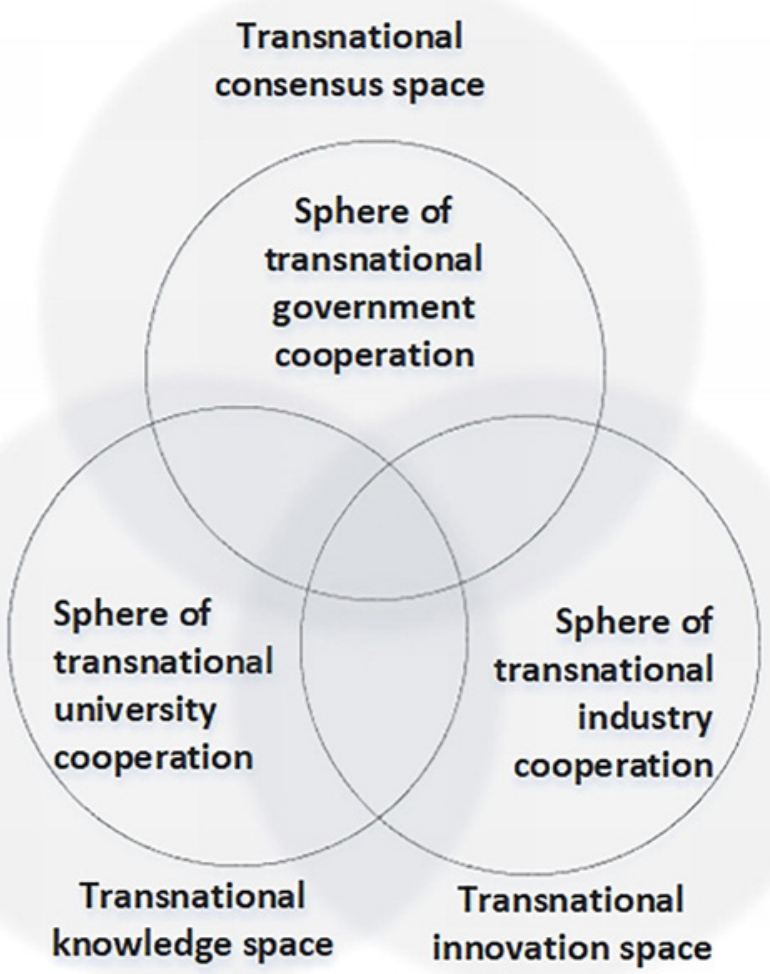

FIgURE 5 Transnational Triple Helix Model SOURCE: MODIFIED FROM CAI ET AL. (2019: 8)

linkages with non-academics Villanueva, Molas-Gallart, and Esteve (2006) found "researchers who have developed an integrated network, with equilibrium between strong and weak ties, archive better outputs" (2006: 19). Other studies on micro-foundations of Triple Helix pay special attention to hybrid organizations in boundary spaces (Champenois \& Etzkowitz 2017) and capacities of key triple helix actors, such as universities (Y. Liu \& Huang 2018). Even more important is to develop meso-level theoretical framework that connects both the macro and micro levels of analysis. For instance, the institutional logics approach integrates both the macro-level social structure and micro level of migration of institutional elements and agency into an integrated analytical lens. Such insight is reflected in Cai and Liu's (2020) investigation on the agency role of individual university leaders, academics and students in changing the institutional logics of local government officials and industry in Yangpu District, Shanghai. 
The Triple Helix value directed innovation project eschews social science that merely describes without prescribing a future direction. Indeed, the need for Triple Helix ethics has been suggested (Etzkowitz 2011). It is clearly seen in recent work why Triple Helix is often implicitly adopted by practitioners and policymakers, who later learn its theoretical elucidation (Gebhardt 2019). It has become more broadly applicable as a methodology for knowledge-based development by specifying the preconditions and practices most suitable for supporting innovation and entrepreneurship. In spite of positive progress in terms of theoretical underpinnings of the Triple Helix model, its explanatory power still has room for improvement through meso-level theories that have the capacity to connect both the macro and micro-level analysis. The validity of the triple helix model is most fundamentally driven by the phenomenon that it attempts to explain the dynamics of innovation in the contemporary society, such as the wide spreading of the entrepreneurial university to academic systems of different historical provenance, divergent objectives and radically different social circumstances.

As the Triple Helix model is firmly rooted in classical sociological theory and institutional economics, it is expected that interdisciplinary perspectives of various social science theories should be used for further enhancing the theoretical foundation of the model. Datta and Saad (2011) in their analysis of Triple Helix development in India suggest that the central mechanism of Triple Helix is intrinsically associated with a mix of different forms of fungible capital, namely economic, human, social and cultural. The perspective of looking at Triple Helix interactions as exchanges of multiple capitals may help combine classic theories about human capital (Becker 1964; Schultz 1961), cultural capital (Weber 1930), social capital (Bourdieu 1986) and value of money (Simmel 1978). The Triple Helix model may serve as a framework to integrate the insights from multiple approaches to innovation studies, while the insights of other approaches can strengthen the theoretical core of Triple Helix. To be more useful, the gap in applied social science, apart from economics, should be remedied (Etzkowitz \& Schaflander 1968).

Although our paper focuses on the theoretical dimension, to fully understand the dynamics of Triple Helix also requires novel methodological approaches. Nowadays, triple helix interactions are increasingly taking place in transnational contexts. As such, the Living Lab method and machine learning technic, integrating social sciences and computer sciences, to capture on-going activities and even predict future tendencies are indicated (Cai et al. 2019). 
Finally, in the face of accelerating complexity, we should take the Occam's razor principle even more seriously. Compared with other approaches in innovation studies, such as innovation system (Edquist 1997; Freeman 1987; Lundvall 1992), open innovation (Chesbrough 2003) and Quadruple Helix (Carayannis \& Campbell 2012), 'the Triple Helix model reduces the complexity of the dynamics at play in the innovation systems of the knowledge economy' (Zheng, 2010: 41). Such a reduction in complexity, allowing essential dynamics to be more clearly discerned, is a key theoretical and practical advantage of the model.

\section{References}

Abrahamson, E., and Rosenkopf, L. (1997). Social Network Effects on the Extent of Innovation Diffusion: A Computer Simulation. Organization Science, 8 (3), pp. 289309. doi:10.1287/orsc.8.3.289.

Adler, E., and Adler, P.E. (1987). The Power of Ideology: The Quest for Technological Autonomy in Argentina and Brazil. Berkeley: University of California Press.

Almeida, M. (2005). The Evolution of the Incubator Movement in Brazil. International Journal of Technology and Globalisation, 1 (2), pp. 258-277. doi:10.1504/ IJTG.2005.007054.

Arnkil, R., Järvensivu, A., Koski, P., and Piirainen, T. (2010) Exploring Quadruple Helix: Outlining user-oriented innovation models. In. Work Research Centre, Working papers 85/2010. Tampere: Institute for Social Research, University of Tampere.

Balzat, M., and Hanusch, H. (2004). Recent Trends in the Research on National Innovation Systems. Journal of Evolutionary Economics, 14 (2), pp. 197-210.

Balzer, H., and Askonas, J. (2016). The Triple Helix after Communism: Russia and China Compared. Triple Helix, 3 (1). doi:10.1186/s4o6o4-o15-oo31-4.

Barnard, H., and Chaminade, C. (2011). Global Innovation Networks: Towards a Taxonomy. circle Working Paper, 4.

Barrie, J., Zawdie, G., and João, E. (2019). Assessing the Role of Triple Helix System Intermediaries in Nurturing an Industrial Biotechnology Innovation Network. Journal of CleanerProduction, 214, pp. 209-223. doi:https://doi.org/10.1016/j.jclepro.2018.12.287.

Battilana, J., Leca, B., and Boxenbaum, E. (2009). How Actors Change Institutions: Towards a Theory of Institutional Entrepreneurship. The Academy of Management Annals, 3(1), 65-107. doi:10.1080/19416520903053598.

Becker, G.S. (1964). Human Capital: A Theoretical and Empirical Analysis, with Special Reference to Education. Chicago: University of Chicago Press.

Benneworth, P., Smith, H.L., \& Bagchi-Sen, S. (2015). Introduction. Industry and Higher Education, 29 (1), pp. 5-10. 
Boschma, R. (2005). Proximity and Innovation: A Critical Assessment. Regional Studies, 39 (1), pp. 61-74. doi:10.1080/0034340052000320887.

Bourdieu, P. (1986). The Forms of Capital. In: J. Richardson, ed., Handbook of Theory and Research for the Sociology of Education. New York: Greenwood, pp. 241-258.

Braithwaite, J.J. (2017). Occam's Razor: The Principle of Parsimony. Available at: https:// www.academia.edu/1742741/Occams_Razor_The_principle_of_Parsimony.

Brundin, E., Wigren, C., Isaacs, E., Friedrich, C., and Visser, K. (2008). Triple Helix Networks in a Multiculral Context: Triggers and Barriers for Fostering Growth and Sustainability. Journal of Developmental Entrepreneurship, 13 (1), pp. 77-98.

Bychkova, O., Chernysh, A., \& Popova, E. (2015). Dirty Dances: Academia-Industry Relations in Russia. Triple Helix, 2 (13). doi:https://doi.org/10.1186/s406o4-015-oo19-o.

Cai, Y. (2014). Implementing the Triple Helix Model in a Non-Western Context: An Institutional Logics Perspective. Triple Helix, 1(1), pp.1-20. doi:10.1186/s406o4-014-ooo1-2.

Cai, Y. (2015). What Contextual Factors Shape "Innovation in Innovation"? - Integration of Insights of the Triple Helix and the Institutional Logics Perspective. Social Science Information, 54 (3), pp. 299-326. doi:10.1177/0539018415583527.

Cai, Y., Ferrer, B.R., and Lastra, J.L.M. (2019). Building University-Industry Co-Innovation Networks in Transnational Innovation Ecosystems: Towards a Transdisciplinary Approach of Integrating Social Sciences and Artificial Intelligence. Sustainability, 11 (17), pp. 1-23. doi:10.339o/su11174633.

Cai, Y., and Lattu, A. (2019, 9-11 September). Civically Grounded Triple Helix: Synergies Between Triple Helix and Quadruple Helix Models of Innovation. Paper presented at the XVII International Triple Helix Conference, Cape Town.

Cai, Y., and Liu, C. (2015). The Roles of Universities in Fostering Knowledge-Intensive Clusters in Chinese Regional Innovation Systems. Science and Public Policy, 42 (1), pp. 15-29. doi:10.1093/scipol/scuo18.

Cai, Y., and Liu, C. (2020). The Role of University as Institutional Entrepreneur in Regional Innovation System: Towards an Analytical Framework. In: M.T. Preto, A. Daniel, and A. Teixeira, eds., Examining the Role of Entrepreneurial Universities in Regional Development. Hershey, PA: IG I Global, pp. 133-155.

Cai, Y., Pugh, R., and Liu, C. (2015). Enabling Conditions for Regional Triple Helix Systems. Helice, 4, pp. 19-23.

Cai, Y., Pugh, R., and Liu, C. (2017). A Framework for Analysing the Role of Innovation Policy in Regional Innovation System Development. International Journal of Innovation and Regional Development, 7 (4), pp. 237-256. doi:10.1504/IJIRD.2017. o86192.

Capaldo, A. (2007). Network Structure and Innovation: The Leveraging of a Dual Network as a Distinctive Relational Capability. Strategic Management Journal, 28 (6), pp. $5^{8} 5^{-608}$. doi: $10.1002 / \mathrm{smj} .621$. 
Carayannis, E.G., and Campbell, D.F.J. (2009). "Mode 3" and "Quadruple Helix": Toward a 21st Century Fractal Innovation Ecosystem. International Journal of Technology Management, 46 (3/4), pp. 201-234.

Carayannis, E.G., and Campbell, D.F.J. (2012). Mode 3 Knowledge Production in Quadruple Helix Innovation Systems. In: Mode 3 Knowledge Production in Quadruple Helix Innovation Systems (Vol. 7). New York: Springer, pp. 1-63.

Carayannis, E.G., Barth, T.D. and Campbell, D.F.J. (2012). The Quintuple Helix innovation model: global warming as a challenge and driver for innovation. Journal of Innovation and Entrepreneurship 1(1), 1-12. doi: 10.1186/2192-5372-1-2.

Champenois, C., and Etzkowitz, H. (2018). From boundary line to boundary space: The creation of hybrid organizations as a Triple Helix micro-foundation. Technovation, 76-77, 28-39. doi:https://doi.org/10.1016/j.technovation.2017.11.0o2.

Cheng, Y.J., Liu, Y., Fan, W., Yan, Z., and Ye, X.T. (2019). Triple Helix on Globalization: A Case Study of the China International Nanotech Innovation Cluster. Information Development, 35 (2), pp. 272-289. doi:10.1177/o26666691774305o.

Chesbrough, H.W. (2003). Open Innovation: The New Imperative for Creating and Profiting from Technology. Boston, MA: Harvard Business School and Maidenhead: McGraw-Hill.

Cooke, P. (2005). Regionally Asymmetric Knowledge Capabilities and Open Innovation:Exploring "Globalisation 2" - A New Model of Industry Organisation. Research Policy, 34 (8), pp. 1128-1149. doi:10.1016/j.respol.2004.12.005.

Daniels, C.U., Ustyuzhantseva, O., and Yao, W. (2017). Innovation for Inclusive Development, Public Policy Support and Triple Helix: Perspectives from Brics. African Journal of Science, Technology, Innovation and Development, 9 (5), pp. 513-527. doi: 1 0.1080/20421338.2017.1327923.

Datta, S., and Saad, M. (2011). Innovation in a Developing Country Context: Developing an Integrated Framework through India's Experience In: M. Saad and G. Zawdie, eds., Theory and Practice of the Triple Helix System in Developing Countries: Issues and Challenges. New York: Routledge, pp. 207-229.

De Oliveira Monteiro, S.P., and Carayannis, E.G. (2017). The Quadruple Innovation Helix Nexus: A Smart Growth Model, Quantitative Empirical Validation and Operationalization for oecd Countries: Palgrave Macmillan US.

Deakin, M. (2014). Smart Cities: The State-of-the-art and Governance Challenge. Triple Helix, 1 (7). Available at: doi:https://doi.org/10.1186/s406o4-014-0oo7-9.

Drori, G.S. (2013). The Helix Model of Innovation in Israel: The Institutional and Relational Landscape of Israel's Innovation Economy (Vol. Bat Drora Publishing): Jerusalem.

Dzisah, J., and Etzkowitz, H. (2008). Triple Helix Circulation: The Heart of Innovation and Development. International Journal of Technology Management \& Sustainable Development, 7 (2), pp. 101-115. 
Edquist, C., ed. (1997). Systems of Innovation: Technologies, Institutions and Organizations. London: Printer.

Elkington, J. (1998). Partnerships from cannibals with forks: The triple bottom line of 21st-century business. Environmental Quality Management, 8(1), 37-51. doi:10.1002/ tqem.3310o8o106.

Etzkowitz, H. (1983). Entrepreneurial Scientists and Entrepreneurial Universities in American Academic Science. Minerva, 21 (2/3), pp. 198-233.

Etzkowitz, H. (1993). Technology Transfer: The Second Academic Revolution. Technology Access Report, 6, pp. 7-9.

Etzkowitz, H. (2002a). Incubation of Incubators: Innovation as a Triple Helix of University-Industry-Government Networks. Science and Public Policy, 29 (2), pp. 115-128. doi:10.3152/147154302781781056.

Etzkowitz, H. (2002b) The Triple Helix of University-Industry-Government: Implications for Policy and Evaluation. In: Working Paper 2002.11. Sweden: Science Policy Institute.

Etzkowitz, H. (2003). Innovation in Innovation: The Triple Helix of UniversityIndustry-Government Relations. Social Science Information, 42 (3), pp. 293-337.

Etzkowitz, H. (2008). The Triple Helix: University-Industry-Government Innovation in Action. New York/London: Routledge.

Etzkowitz, H. (2011). Normative Change in Science and the Birth of the Triple Helix. Social Science Information, 5o (3/4), pp. 549-568. doi:10.1177/0539018411411403.

Etzkowitz, H. (2013). Silicon Valley at Risk? Sustainability of a Global Innovation Icon: An Introduction to the Special Issue. Social Science Information, $5^{2}$ (4), pp. 515-538. doi:10.1177/0539018413501946.

Etzkowitz, H. (2014). Making a Humanities Town: Knowledge-infused Clusters, Civic Entrepreneurship and Civil Society in Local Innovation Systems. Triple Helix, 2 (1). https://doi.org/10.1186/s406o4-014-oo12-z.

Etzkowitz, H., Bikkulov, A., Kovaleinen, A., Leitner, K.H., Poutanen, S., Grey, D., et al. (2017). Metrics for the Entrepreneurial University. Triple Helix Working Papers.

Etzkowitz, H., and Dzisah, J. (2012). The Age of Knowledge: The Dynamics of Universities, Knowledge \& Society. Leiden: Brill.

Etzkowitz, H., Gulbrandsen, M., and Levitt, J. (2000). Public Venture Capital: Government Funding Sources for Technology Entrepreneurs. New York: Harcourt.

Etzkowitz, H., and Leydesdorff, L. (1995). The Triple Helix. University-IndustryGovernment Relations: A Laboratory for Knowledge-Based Economic Development. easst Review, 14, pp. 14-19.

Etzkowitz, H., and Leydesdorff, L. (2000). The Dynamics of Innovation: From National Systems and "Mode 2" to a Triple Helix of University-Industry-Government Relations. Research Policy, 29 (2), pp. 109-123. doi:10.1016/Soo48-7333(99)ooo55-4. 
Etzkowitz, H., and Leydesdorff, L., eds., (1997). Universities and the Global Knowledge Economy: A Triple Helix of University-Industry-Government Relations. London: Printer.

Etzkowitz, H., and Schaflander, G.M. (1968). A Manifesto for Sociologists: Institution Formation. A New Sociology. Social Problems, 15 (4), pp.399-408. doi:10.2307/799828.

Etzkowitz, H., and Steiber, A. (2018). Silicon Valley's Paradox of Success: A Katrina Efect. In: C.F. Nourani (Ed.), Computing Predictive Analytics, Business Intelligence, and Economics: Modeling Techniques with Start-ups and Incubators: Apple Academic Press.

Etzkowitz, H., and Zhou, C. (2006). Triple Helix Twins: Innovation and Sustainability. Science and Public Policy, 33 (1), pp. 77-83.

Etzkowitz, H., and Zhou, C. (2017). The Triple Helix: University-Industry-Government Innovation and Entrepreneurship. Abingdon: Routledge.

Etzkowitz, H., and Zhou, C. (2018). Innovation Incommensurability and the Science Park. R\&D Management, 48 (1), pp. 73-87. doi:10.1111/radm.12266.

European Commission. (2014a). Internal Guidance on Ex Ante Conditionalities for the European Structural and Investment Funds. Available at: http://ec.europa.eu/ regional_policy/sources/docgener/informat/2014/eac_guidance_esif_part1_en.pdf.

European Commission. (2014b). National/Regional Innovation Strategies for Smart Specialisation (ris3). Available at: http://ec.europa.eu/regional_policy/sources/ docgener/informat/2014/smart_specialisation_en.pdf.

European Commission. (2016). The horizon 202 Work Programme 2016-2017 Science with and for Society (European Commission Decision C(2016)8265 of 13 December 2016).

Fagerberg, J., Martin, B.R., and Andersen, E.S. (2013). Innovation studies: Towards a new agenda. In J. Fagerberg, B.R. Martin, \& E.S. Andersen (Eds.), Innovation Studies: Evolution and Future Challenges. Oxford: Oxford University Press, pp. 1-17.

Foray, D. (2015). Smart Specialisation: Opportunities and Challenges for Regional Innovation Policy. Abingdon: Routledge.

Freeman, C. (1987). Technology Policy and Economic Performance: Lessons from Japan. London: Pinter.

Friedman, T.L. (2005). The World is Flat: A Brief History of the Globalized World in the Twenty-First Century. London: Allen Lane.

Gebhardt, C. (2019). The Impact of Participatory Governance on Regional Development Pathways: Citizen-driven Smart, Green and Inclusive Urbanism in the Brainport Metropolitan Region. Triple Helix. doi:https://doi.org/10.1163/21971927-00601003.

Giuliani, E., and Arza, V. (2009). What Drives the Formation of "Valuable" UniversityIndustry Linkages? Insights from the Wine Industry. Research Policy, 38 (6), pp. 9o6-921. doi:10.1016/j.respol.2009.02.0o6.

Granovetter, M.S. (1973). The Strength of Weak Ties. American Journal of Sociology, 78 (6), pp. 136o-138o. doi:10.1086/225469. 
Gretzinger, S., Hinz, H., and Matiaske, W. (2011). Strong Ties, Weak Ties and the Management of Innovation: The Case of Danish and German SMEs. In: M. Tuunanen, J. Windsperger, G. Cliquet, \& G. Hendrikse, eds., New Developments in the Theory of Networks: Franchising, Alliances and Cooperatives. Heidelberg: Physica-Verlag HD, pp. 277-298.

Hahn, T., Pinkse, J., Preuss, L., and Figge, F. (2015). Tensions in Corporate Sustainability: Towards an Integrative Framework. Journal of Business Ethics, 127(2), 297-316. doi:10.1007/s10551-014-2047-5.

Hiltzik, M.A. (200o). Dealers of Lightning : Xerox parc and the Dawn of the Computer Age. New York: Harper.

Hladchenko, M., and Pinheiro, R. (2019). Implementing the Triple Helix Model: Means-Ends Decoupling at the State Level? Minerva, 57 (1), pp. 1-22. doi:10.1007/ s11024-018-9355-3.

Ivanova, I. (2014). Quadruple Helix Systems and Symmetry: a Step Towards Helix Innovation System Classification. Journal of the Knowledge Economy, 5 (2), pp. 357-369. doi:10.1007/s13132-014-0201-z.

Jackson, D. (2011). What is an Innovation Ecosystem? Available at: http://erc-assoc .org/sites/default/files/topics/policy_studies/DJackson_Innovation\%2oEcosys tem_o3-15-11.pdf.

Juma, C. (2016). Innovation and its Enemies: Why People Resist New Technologies: Oxford: Oxford University Press.

Kenney, M., and Zysman, J. (2016). The Rise of the Platform Economy. Issues in Science and Technology, 32 (3), pp. 61-69.

Kim, M., and Park, H.W. (2012). Measuring Twitter-based Political Participation and Deliberation in the South Korean Context by using Social Network and Triple Helix Indicators. Scientometrics, 90 (1), pp. 121-140. doi:10.1007/s11192-011-0508-5.

Kreusel, N., Roth, N., and Brem, A. (2018). European Business Venturing in Times of Digitisation - An Analysis of For-Profit Business Incubators in a Triple Helix Context. International Journal of Technology Management, 76 (1/2), pp. 104-136. doi:10.1504/ijtm.2018.088707.

Kimatu, J.N. (2016). Evolution of strategic interactions from the triple to quad helix innovation models for sustainable development in the era of globalization. Journal of Innovation and Entrepreneurship, 5(1), 16. doi:10.1186/s13731-016-oo44-x.

Kumari, M., and Mallick, S. (2017). Triple Helix Model of Innovation and the Politics of Genetically Modified Crops: Cases of Bt Cotton and Bt Brinjal in India. Perspectives on Global Development and Technology, 16 (4). doi:10.1163/15691497-12341443.

Kwon, K.-S., Park, H.W., So, M., and Leydesdorff, L. (2012). Has Globalization Strengthened South Korea's National Research System? National and International Dynamics of the Triple Helix of Scientific Co-authorship Relationships in South Korea. Scientometrics, 90 (1), pp. 163-176. doi:10.1007/s11192-011-0512-9. 
Lattu, A., and Cai, Y. (2020). Tensions in the Sustainability of Higher Education - The Case of Finnish Universities. Sustainability, 12 (5), p. 1941.

Levin, D.Z., and Cross, R. (2004). The Strength of Weak Ties You Can Trust: The Mediating Role of Trust in Effective Knowledge Transfer. Management Science, $5^{\circ}$ (11), pp. 1477-149o.

Leydesdorff, L. (2000). The Triple Helix: An Evolutionary Model of Innovations. Research Policy, 29 (2), pp. 243-255. doi:10.1016/soo48-7333(99)ooo63-3.

Leydesdorff, L. (2003). The Mutual Information of University-Industry-Government Relations: An Indicator of the Triple Helix Dynamics. Scientometrics, $5^{8}(2)$, pp. 445-467. doi:10.1023/a:1026253130577.

Leydesdorff, L. (2012). The Triple Helix, Quadruple Helix, ..., and an $N$-Tuple of Helices: Explanatory Models for Analyzing the Knowledge-Based Economy? Journal of the Knowledge Economy, 3 (1), pp. 25-35. doi:10.1007/s13132-011-0049-4.

Leydesdorff, L. (2018). Synergy in Knowledge-Based Innovation Systems at National and Regional Levels: The Triple-Helix Model and the Fourth Industrial Revolution. Journal of Open Innovation: Technology, Market, and Complexity, 4 (2), pp. 1-13.

Leydesdorff, L., and Deakin, M. (2011). The Triple-Helix Model of Smart Cities: A NeoEvolutionary Perspective. Journal of Urban Technology, 18 (2), pp. 53-63. doi:10.108o /10630732.2011.6o1111.

Leydesdorff, L., and Etzkowitz, H. (2003). Can "The Public" Be Considered as a Fourth Helix in University-Industry-Government Relations? Report of the Fourth Triple Helix Conference. Science \& Public Policy, 30 (1), pp. 55-61.

Leydesdorff, L., and Fritsch, M. (2006). Measuring the Knowledge Base of Regional Innovation Systems in Germany in Terms of a Triple Helix Dynamics. Research Policy, 35 (10), pp. 1538-1553. doi:https://doi.org/10.1016/j.respol.2006.o9.o27.

Leydesdorff, L., and Meyer, M. (2003). The Triple Helix of University-IndustryGovernment Relations. Scientometrics, $5^{8}$ (2), pp. 191-203. doi:10.1023/a:102627630 8287 .

Leydesdorff, L., and Meyer, M. (2006). Triple Helix Indicators of Knowledge-based Innovation Systems: Introduction to the Special Issue. Research Policy, 35 (10), pp. 1441-1449. doi:10.1016/j.respol.2006.o9.o16.

Leydesdorff, L., and Park, H.W. (2014). Can Synergy in Triple Helix Relations be Quantified? A Review of the Development of the Triple Helix Indicator. Triple Helix, 1 (4). doi:https://doi.org/10.1186/s40604-014-ooo4-z.

Leydesdorff, L., Perevodchikov, E., and Uvarov, A. (2015). Measuring Triple-Helix Synergy in the Russian Innovation Systems at Regional, Provincial, and National Levels. Journal of the Association for Information Science and Technology, 66 (6), pp. 12291238. doi:10.1002/asi.23258.

Leydesdorff, L., and Zhou, P. (2014). Measuring the Knowledge-based Economy of China in Terms of Synergy among Technological, Organizational, and Geographic 
Attributes of Firms. Scientometrics, 98 (3), pp. 1703-1719. doi:10.1007/s11192-0131179-1.

Lindberg, M., Lindgren, M., and Packendorff, J. (2014). Quadruple Helix as a Way to Bridge the Gender Gap in Entrepreneurship: The Case of an Innovation System Project in the Baltic Sea Region. Journal of the Knowledge Economy, 5 (1), pp. 94-113. doi:10.1007/s13132-012-0098-3.

Liu, C., and Cai, Y. (2018). Triple Helix Model and Institutional Logics in Shenzhen Special Economic Zone. Science and Public Policy, 45 (2), 221-231. doi:10.1093/scipol/ scxo59.

Liu, J., Chaminade, C., and Asheim, B. (2013). The Geography and Structure of Global Innovation Networks: A Knowledge Base Perspective. European Planning Studies, 21 (9), pp. 1456-1473. doi:10.108o/og654313.2012.755842.

Liu, X., and White, S. (2001). Comparing Innovation Systems: A Framework and Application to China's Transitional Context. Research Policy, 30 (7), pp. 1091-1114. doi:10.1016/soo48-7333(oo)oo132-3.

Liu, Y., and Huang, Q. (2018). University Capability as a Micro-Foundation for the Triple Helix Model: The Case of China. Technovation, 76/77 (August/September), pp. 405o. https://doi.org/10.1016/j.technovation.2018.02.013.

Lundvall, B.-Å., ed. (1992). National Systems of Innovation: Towards a Theory of Innovation and Interactive Learning. London, New York: Pinter Publishers.

Mandrup, M., and Jensen, T.L. (2017). Educational Action Research and Triple Helix Principles in Entrepreneurship Education: Introducing the EARTH Design to Explore Individuals in Triple Helix Collaboration. Triple Helix, 4 (1). doi:https://doi .org/10.1186/s406o4-017-0048-y.

Marcovich, A., and Shinn, T. (2011). From the Triple Helix to a Quadruple Helix? The Case of Dip-Pen Nanolithography. Minerva, 49(2), 175-19o. doi:10.1007/s11024-0119169-z.

Martin, R. (2018, 26 April). Comments at the Industrial Policy Symposium, University of Bath, 26 April 2018.

Megnigbeto, E. (2018). Modelling the Triple Helix of University-Industry-Government Relationships with Game Theory: Core, Shapley Value and Nucleolus as Indicators of Synergy within an Innovation System. Journal of Informetrics, 12 (4), pp. 1118-1132. doi:10.1016/j.joi.2018.o9.005.

Mêgnigbêto, E. (2019). Synergy within the West African Triple Helix Innovation Systems as Measured with Game Theory. Journal of Industry-University Collaboration, 1(2), 96-114. doi:10.1108/JIUC-o3-2019-0oo8.

Meyer, J.W., and Rowan, B. (1977). Institutionalized Organizations: Formal Structure as Myths and Ceremony. American Journal of Sociology, 83 (2), pp. 340-363.

Michelfelder, I., and Kratzer, J. (2013). Why and How Combining Strong and Weak Ties within a Single Interorganizational R\&D Collaboration Outperforms Other 
Collaboration Structures. Journal of Product Innovation Management, 30 (6), pp. 1159-1177. doi:10.1111/jpim.12052.

Miller, K., McAdam, R., and McAdam, M. (2018). A Systematic Literature Review of University Technology Transfer from a Quadruple Helix Perspective: Toward a Research Agenda. R\&D Management, 48 (1), pp. 7-24. doi:10.1111/radm.12228.

Mowery, D.C., and Sampat, B.N. (2004). Universities in National Innovation Systems. In: J. Fagerberg, D.C. Mowery, \& R.R. Nelson (Eds.), The Oxford Handbook of Innovation. Oxford and New York: Oxford University Press, pp. 209-239.

Necoechea-Mondragón, H., Pineda-Domínguez, D., Pérez-Reveles, L., and Soto-Flores, R. (2017). Critical Factors for Participation in Global Innovation Networks. Empirical Evidence from the Mexican Nanotechnology Sector. Technological Forecasting and Social Change, 114 (Supplement C), pp. 293-312. doi:https://doi.org/10.1016/j .techfore.2016.08.027.

Pandey, N., and Desai, P.N. (2017). Exploring “Global Innovation Networks" in Bio Clusters: A Case of Genome Valley in Hyderabad, India. Journal of Scientometric Research, 6 (1), pp. 23-35. doi:10.5530/jscires.6.1.4.

Doh, P. (2018). A Quadruple Helix Framework for University-led Community Innovation Systems in Africa. In: E. Pekkola, J. Kivisto, V. Kohamaki, Y. Cai, and A. Lyytinen, eds., Theoretical and Methodological Perspectives of Higher Education Management and Transformation: An Advanced Reader for PhD Students. Tampere: University of Tampere press, pp. 87-104.

Patra, S.K., and Muchie, M. (2018). Research and Innovation in South African uUniversities: From the Triple Helix's Perspective. Scientometrics, 116 (1), pp. 51-76. doi:10.1007/s11192-018-2764-o.

Peng, F., Zhang, Q.Q., Han, Z.L., Ding, Y., and Fu, N.N. (2019). Evolution Characteristics of Government-Industry-University Cooperative Innovation Network of Electronic Information Industry in Liaoning Province, China. Chinese Geographical Science, 29 (3), pp. 528-540. doi:10.1007/s11769-019-1047-x.

Pinto, H. (2017). Connecting the Triple Helix Space: Actor-Network Creation and Institutionalisation of Knowledge Transfer Offices. Triple Helix, 4 (1). doi:10.1186/ s40604-017-0045-1.

Pique, J.M., Miralles, F., Teixeira, C.S., and Gaspar, J.V. (2019). Application of the Triple Helix Model in the Revitalisation of Cities: The Case of Brazil. International Journal of Knowledge-Based Development 10 (1), pp. 43-74. doi:10.1504/IJKBD.2019.098230.

Poppen, F., Decker, R. (2018). The Intermediary as an Institutional Entrepreneur: Institutional Change and Stability in Triple-Helix Cooperation. Triple Helix, 5 (9). doi:https://doi.org/10.1186/s406o4-018-oo63-7.

Ranga, M., Etzkowitz, H. (2013). Triple Helix Systems: An Analytical Framework for Innovation Policy and Practice in the Knowledge Society. Industry and Higher Education, 27 (4), pp. 237-262. 
Reich-Graefe, R. (2016). Intermediation in Intermediation: Triple Helix Innovation and Intermediary Legal Organisation. Triple Helix, 3 (10). Available at: doi:https://doi .org/10.1186/s40604-016-0o41-x.

Rice, M. (2019, 9-13 August). Incubators/Accelerators as Catalysts in Entrepreneurship Ecosystems. Paper presented at the 79th Annual Meeting of the Academy of Management, Boston, MA.

Rutten, R., Boekema, F. (2012). From Learning Region to Learning in a Socio-spatial Context. Regional Studies, 46 (8), pp. 981-992. doi:10.108o/oo343404.2012.712679.

Saad, M., Datta, S., Razak, A.A. (2017). University-Industry Relationships in Developing Countries: Opportunities and Challenges in Algeria, Indonesia, Malaysia and India. International Journal of Technology Management \& Sustainable Development, 16(2), 175-19o. doi:10.1386/tmsd.16.2.175_1.

Saad, M., Zawdie, G. (2011). Theory and Practice of the Triple Helix System in Developing Countries: Issues and Challenges. New York: Routledge.

Schultz, T.W. (1961). Investment in Human Capital. The American Economic Review, 51 (1), pp. 1-17.

Scott, W.R., Kirst, M.W., Biag, M., Sipes, L. (2017). Introduction. In: W.R. Scott, M.W. Kirst, et al., eds., Higher Education and Silicon Valley. Baltimore: Johns Hopkings University Press.

Scott, W.R., Kirst, M.W., et al. (2017). Higher Education and Silicon Valley. Baltimore: Johns Hopkings University Press.

Seppälä, P. (1992). Civil Society in the Making: People's Organizations and Politics in the Third World. Helsinki: Institute of Development Studies, University of Helsinki.

Shinn, T. (2002). The Triple Helix and New Production of Knowledge: Prepackaged Thinking on Science and Technology. Social Studies of Science, 32 (4), pp. 599-614.

Simmel, G. (1978). The Philosophy of Money. London and Boston, MA: Routledge and Kegan Paul.

Solesvik, M.Z. (2017). The Triple Helix Model for Regional Development and Innovation: Context of Nordic Countries. Forum Scientiae Oeconomia, 5 (4), pp. $5^{-21}$.

Speakman, J., Afzal, K., Yuge, Y., Hanna, J. (2012). Toward an Innovation Policy for Pakistan. World Bank Policy Paper Series on Pakistan. Available at: http://documents .worldbank.org/curated/en/463051468287783692/pdf/86242oNWPoWorlo6201200oInnovation.pdf.

Swar, B., Khan, G.F. (2013). An analysis of the information technology outsourcing domain: A social network and Triple helix approach. Journal of the American Society for Information Science and Technology, 64 (11), pp. 2366-2378. Available at: doi:10.1002/asi.22918.

Tamtik, M. (2018). “Innovation Policy is a Team Sport”. Insights from Non-governmental Intermediaries in Canadian Innovation Ecosystem. Triple Helix, 5 (8). doi:https:// doi.org/10.1186/s406o4-018-0o62-8. 
Thornton, P.H., Ocasio, W., and Lounsbury, M. (2012). The Institutional Logics Perspective : A New Approach to Culture, Structure and Process. Oxford: Oxford University Press.

Tuunainen, J. (2002). Reconsidering the Mode 2 and the Triple Helix: A Critical Comment Based on a Case Study. Science Studies, 15 (2), pp. 36-58.

University of Bath. (2018). The Golden Triangle of Business, Government and Academia - Challenges and Benefits. Available at: https:/www.bath.ac.uk/events/ the-golden-triangle-of-business-government-and-academia-challenges-andbenefits/.

Ustundag, A., Cevikcan, E.A. (2018). Industry 4.o: Managing the Digital Transformation. Springer International Publishing.

Viale, R., Etzkowitz, H. (2010). The Capitalization of Knowledge: a Triple Helix of University-Industry-Government. Cheltenham: Edward Elgar.

Viale, R., Pozzali, A. (2010). Complex Adaptive Systems and the Evolutionary Triple Helix. Critical Sociology, 36 (4), pp. 575-594. Available at: doi:10.1177/o8969205103 65923.

Villanueva, A., Molas-Gallart, J., Esteve, A.E. (2006). Measuring Triple Helix Linkages: A Contribution from Embeddedness Theory. Paper presented at the The 6th Biennial International Conference on University, Industry and Government Linkages, Singapore. Available at: http://digital.csic.es/bitstream/10261/10165/1/AC164_1_\%C3\%81 frica-Jordi-mayo-2007-Singapur.presentation-6thTripleHelix\%252opaper.pdf.

Walsh, D. (1979). Occam's Razor: A Principle of Intellectual Elegance. American Philosophical Quarterly, 16 (3), pp. 241-244.

Weber, M. (1930). The Protestant Ethic and the Spirit of Capitalism. London: George Allen \& Unwin Ltd.

Wolff, K.H., ed. (1950). The Sociology of Georg Simmel. Glencoe, IL: Free Press.

Ye, F.Y., Yu, S.S., Leydesdorff, L. (2013). The Triple Helix of University-IndustryGovernment Relations at the Country Level and its Dynamic Evolution under the Pressures of Globalization. Journal of the American Society for Information Science and Technology, 64 (11), pp. 2317-2325. doi:10.1002/asi.22931.

Ye, W., Wang, Y. (2019). Exploring the Triple Helix Synergy in Chinese National System of Innovation. Sustainability, 11 (23), p. 6678.

Yoda, N., Kuwashima, K. (2019). Triple Helix of University-Industry-Government Relations in Japan: Transitions of Collaborations and Interactions. Journal of the Knowledge Economy, Online first. doi:10.1007/s13132-019-00595-3.

Yoon, J., Park, H.W. (2017). Triple Helix Dynamics of South Korea's Innovation System: A Network Analysis of Inter-regional Technological Collaborations. Quality \& Quantity, 51 (3), pp. 989-1007. doi:10.1007/s11135-016-o346-x.

Zheng, P. (2010). The "Second Academic Revolution": Interpretations of Academic Entrepreneurship. Canadian Journal of Higher Education, 40 (2), pp. 35-5o. 
Zhou, C. (2008). Emergence of the Entrepreneurial University in Evolution of the Triple Helix: The Case of Northeastern University in China. Journal of Technology Management in China, 3 (1), pp. 109-126. Available at: https://doi.org/10.1108/ 17468770810851539 .

Zhou, C. (2014). Four Dimensions to Observe a Triple Helix: Invention of "Cored Model" and Differentiation of Institutional and Functional Spheres. Triple Helix, 1 (1), pp. 1-2o. Available at: https://doi.org/10.1186/s406o4-014-oo11-o. 